\title{
DEVELOPMENT DIRECTIONS FOR THE TOURISM OFFER OF THE ALBA IULIA FORTRESS. QUALITATIVE ASSESSMENTS
}

\author{
Lucian Marina ${ }^{l}$ \\ Andreea Muntean ${ }^{2}$ \\ Claudiu Stefani ${ }^{3}$
}

\begin{abstract}
Achieving an integrated cultural and historic tourism offer is the main direction of the tourism development strategy for the Alba Iulia Fortress. The practice of implementing any strategy shows us that during this process a series of complementary or even antithetic projects and visions will occur. Through qualitative assessments, based on a focus-group type of investigations with experts in tourism, architecture and city planning, we suggest adjustments or even new development projects for the Fortress.
\end{abstract}

Key Words: touristic offer, cultural tourism, tourism development

JEL codes: M31, L83

\section{Introduction}

Between the years 2007 and 2009, the Vauban Fortress has been the object of some quantitative and qualitative marketing researches that targeted to underlie the tourism development directions. The partial results of these investigations have shaped the idea that the habitants of the town can be the main direct or indirect beneficiaries of the Fortress' development (Bolog, Marina, 2008). Achieving an exceptional cultural and historic tourism is the main direction for the tourism development wanted by the citizens of this town. The most important visions of the people, extracted from our researches conducted between 2007 and 2008, were: the medieval atmosphere (with carriages, costumes, but also events with contemporary music) and monumental historic set ups of the Fortress's space (such as: medieval belvedere tower, Roman amphitheatre or medieval inn). The respondents saw as required conditions for tourism development the cleanness of the grass plot, well signaled alleys and routes, as well as restricting auto traffic in the area. The commerce option targets the cultural-historic commerce, those who accept other types of commercial activities as a development option are a minority. At the same time, a modern real-estate development of the Fortress is not looked upon well either (offices or localizations of public institutions).

This present study, which continues the quantitative researches done by the authors in 2008 , wants to validate the opinions of the respondets and even to bring forward new development projects for the Fortress through qualitative assessments, mainly based on the methods of the individual and group interview. Focusing on the focus-group method was done because it is extremely useful for assessing products or strategies (R. A. Krueger, M. A. Casey, 2005). The marketing research that was conducted has the feature of a branding study also (Datculescu, 2006).

\footnotetext{
1"1 Decembrie 1918" University of Alba Iulia, e-mail: marina_frds@yahoo.com

2"1 Decembrie 1918" University of Alba Iulia, e-mail: bologandreea@yahoo.com

31 Decembrie 1918" University of Alba Iulia
} 


\section{The Qualitative Methodology}

Focus group interviews were conducted with the local leaders in order to validate the results of the sociological and marketing research regarding the options of the habitants of Alba Iulia towards the urban regeneration (revitalisation) of the Vauban Fortress.

As general conclusions, we can say that most of the population's options were validated, others were amended and only a few were rejected with arguments.

\section{The Qualitative Study's Results}

Ideas that can be the base of the development project for the tourism product "Alba Iulia Fortress" came off as a result of the interviews.

The investigation came to the result that the historic fortress is the most important and valuable tourism product of the community, a fact agreed with by everybody who was interviewed. The respondents showed that there aren't enough joint efforts in order to valorise the Fortress, the precise actions run by different parties were noticed, their visions and interests seeming rather different than conjoint. The merit of certain restoration and capitalization projects of the historic vestiges was acknowledged, but there are objections regarding the final product where there is no delimitation between what was restored and what was preserved as it was (for example, the Gates of the Fortress).

Among the promotional activities suggested by those who were interview are mentioned the following:

- Advertising through the local media partners;

„One of ideas used by the Mayor's Office to promote the Fortress is through mass-media, through national or private stations, we also have a project to put up boards at the city entrances from Cluj and Sebes, boards that will show images inside the Fortress, as well as boards through-out the city that will invite guests to these values we own. This is what the Mayor's Office wants to do for a better promotion of the Fortress. It would have been good to have in front of us the large project of the Fortress, with the bulwarks, with the two options, the one that was before the Unification" (C.P., city planning counsellor)

- tourism information spots;

„I was on a trip in a town in Germany where I was for the first time, we didn't know where to look for accomodation. At the town's entry we found an information spot, we told them we're looking for accomodation, they searched for information and drew us a map and sent us from that information spot to the accomodation unit. Such a spot requires an investment; in the future, the advertising and information issues will probably be part of a larger programme, which more agents will be a part of, in the future. The thing is that every information about the Fortress must reach economic agents, and this information will return as service requests. There are economic agents specialized on certain services, us, as a tourism agency, don't have the necessary time or the availability to take care of everything, that's why you have to let others and the local authorities to take care of certain projects". (L.N., tourism agency owner)

- public authorities subsidising tourism routes that will include the Fortress;

„We tested the field for these routes. Regarding big routes, they are organized by companies with potential and taking part in them requires very small commissions, it is a work done with passion, but it's no longer a business and therefore you must do something that you can control and this is an area of the county you can rely on, you can bring together all the atractions and make them functional. If you have a group of tourists that you pick-up from the airport, you can take them for a glass of wine, but you can also make time for horse-riding, golf, you can take them to Scărişoara, to the Fortress, it depends on the scheduale you make and on their preferences. The idea is that people can't manage alone, you must get involved if you want your business to work and then there's nobody to depend on for a market study; it's clear that it's an activity for those who have time, 
money from other sources and can conceive these schedules, so a public authority is likely the most suitable”. (A.M., tourism agency owner)

- Spots aired by local radios and televisions;

- The updating of the website that promotes the Fortress;

- Putting at the disposal of the citizens, tourists and visitors materials like postcards, brochures, multimedia materials - that include images, documentaries, information about various events;

„We could say there aren't enough promotion materials for those who visit a historic attraction. When somebody arrives at the objective, he should have the opportunity to know how many visitors have been before him, how many habitants the town has, what other places can he visit. I saw in Austria, where I went for a skiing trip, that brochures give the tourists the opportunity to choose their next spot they would like to visit; there were brochures of two pages that showed advertisings with tourist attractions". (G.A., tourism agency owner)

- Conducting history lessons with the pupils from Alba Iulia, but also from other schools in the county, at the objectives inside the Fortress;

"Set up history lessons with certain categories of pupils at the attractions inside the Fortress, school competions like „Let's get to know, let's discover the Fortress”, etc.”. (B.A., archiepiscopacy spoke-person)

- The info-kiosk and the screens are modern methods for receiving information, but the clients are not sufficiently prepared to use them in a civilized manner. This is because they are exposed to the risk of fast degradation or vandalism, (examples of vandalism on the infoboards placed through projects implemented in the last decade are given). That's why they must be placed in key spots, next to the attractions and be guarded;

- Advertising through interactive, tourism websites with accommodation within family homes;

„Providing support to the families that want to accomodate tourists, registering them on interactive websites of tourist networks. The existence of these networks in France has led to an explosive tourism developement in areas without hotels. When you register in such a programme, you are contacted by somebody who makes on offer. There is a website where you sign-up because you're looking for accommosation in a certain location, the accommodation is offered for free and then another location in next. As a result of the contribution that the person who offers accommodation has, he receives points and these points can be increased or lowered by the satisfation of the tourist. This type of tourism is absolutely individual, it doesn't follow a pattern and it doesn't have preestablished objectives. Knowing the inpour of tourists who visit the city like this, you, as a tourism agency, can greet them with certain programmes and offer them the tourism package they desire". (L.D., tourism agency owner)

The main tourism product, The Route of the Three Fortifications, should be the most promoted objective because it is the modern expression of the historic touristic product, but it is considered that there are many other sites that can acquire the same attraction function for the clients with minimal improvements. As an example are given the medieval structures (the Fortress Bulwarks, the Apor Palace, the Episcopal Palace, the two Cathedrals, the Batthyaneum Library). The Unification Museum would have a touristic value due to the lack of cultural events that rarely take place here. A ,live”, interactive tourism is needed. Without developing a complex tourism unit, with multiple and in train attracttions, we won't have regular visitors from abroad.

„Until we won't have a tourism unit within the Fortressm, who will be the potential visitors? State schools, which will plan trip like „Let's get to know our country”. Our agency was asked by a school to draw up a touristic intinerary for such a project, which required low costs for accommodation and no hotels, meaning a cheap tourism. We had requstes from abroad only 
occasionally, but I remember that a few months ago we had a few people from Greece who contacted us through the Internet, they were in the area for a work appointment, their host told me that they have unlimited budget and to make them feel good. We took them to Cetate Hotel where they served a meal, from there we showed them the attractions in the Fortress, the Cathedral, the Gates, the museum and everything else, we took them to Valea Sebeşului, we showed them two dams and they were very excited. Practically they were business men who requested that somebody took care of their guests because they didn't have the time”. (S.P., tourism agency owner)

Regarding the option to build a belvedere tower within the fortress, the respondents brought up serious objections. They say there are plenty historic buildings that provide views over the entire Fortress (the towers of the two Cathedrals or the attic of the Batthyaneum Library) and, with minimum improvements, they can be used as belvedere spots for the visitors.

The values that should be at the core of promoting the „Alba Iulia Fortress" are primarily spiritual and multicultural, which were neglected by most projects implemented so far. The fact that just a few meters apart are two cathedrals of two different religions with major impact in Europe, Catholicism and Orthodoxy, is a aspect that wasn't yet capitalized.

The lack of infrastructure, arrangements and facilities is still obvious. The indicators, alleys, green spaces and recreation spaces (coffee-shops, restaurants) are still barriers for many of the potential tourists. There aren't enough efforts to provide public toilets that meet the hygiene standards. Eco-toilets placed near touristic sites is a good initiative, but their maintenance is poor. The absence of this elementary aspect in tourism services is one of the causes of the tourists' short stay within the Fortress. The average time for a visit is less than an hour, which means the resources are wasted by both parties: the supplier and the client. The space of the Fortress, especially the bulwarks, requires many works of rehabilitation for the infrastructure, among which the most mentioned are: the urban furniture, public lighting, e-information, e-governing.

The stakeholders have emphasized the need to develop cultural events in open air and, on these lines, the idea to set up an open air amphitheatre within the space of the Fortress seems viable (by observing the legal stipulations and the options of the patrimony holders).

Although the feature of Vauban fortresses is the science of capitalizing the territory (the socalled ,territorial intelligence" concept, which symbols the emergence and the close relation of the space's exploitation method with all its resources), in the case of the Alba Iulia Fortress there is a rupture effect between the two territorial components (the area of the historic monuments and the bulwark area). This is due to the perverse effect (meaning the unwanted entirety effects, although the point wise assessments were accurate) of the successive architectural and administrative projects. None of the recent projects diminish the cleavage: the bulwark area is largely inaccessible to the public (and when is open it becomes a commercial and mass-entertainment destination), and on the other hand, there is the other side, which is predominately sober, without mass entertainment (the museum, the cathedrals, the palaces, the libraries and even the University). The impressions, the lived experience, the wishes of those who visit the fortress, either as tourists, or as visitors, don't tend to lead to a unitary ,background” - the first stage of implementing a BRAND of the Fortress. In these conditions, the local mass-media doesn't have the opportunity to do an active promotion, based on events, the only big ebullient moments presented by the press are the National Holiday and the Town's festivities.

The people who were interviewed said that there is no proper management of the „Alba Iulia Fortress" tourism product. There are several owners of this ,,product" and they can't manage to start a sufficiently constructive dialog. This is mainly due to the lack of vision and the absence of a joint capitalization strategy.

„Private partnerships don't really exist, from all the spaces inside the Fortress there are only two that a private partneship invested in; the Local Council approved certain facilities. It's good for those who want to invest within the Fortress, but only a few wanted and started to do 
something because there are very restrictive ideas concerning these spaces". (C.P., city planning counsellor)

Keeping in mind an integrated management of the Fortress, the suggestions of those who were interviewed target aspects related to actual actions, which are absolutely necessary: the accurate inventory of the capitalized tourism objectives, but also of the ones with capitalizing potential; a market study that would reflect the social and demographic features of the tourists and the preferences regarding touristic objectives, facilities, endowments and infrastructure, taking on the responsabilities for putting them along the touristic circuit, which can be done during meetings and debates.

Regarding the general opinion among people that management public institutions shouldn't be moved within the Fortress, the experts bring arguments (especially local counsellors, but also cultural caretakers) that projects like the Mayor's Office and the Culture Palace can contribute to the integrated management of the Fortress.

A. Problems and projects of the historic fortress' tourism development

1. The problem: the existence of imbricate historic sites and their poor architectural correlation.

Suggested projects:

- The protection, signalling and putting forward all the archaeological sites

- Rebuilding and putting forward the access in the Fortress from the west side

- Rehabilitating and reconversing with administrative, but also cultural and visiting functions of the Princely Palace

- Putting forward and giving touristic functions to the Batthyaneum Library

- Opening the Astronomic Observatory for the public

2. The problem: the absence of a visiting route with a single entrance, which exists for most Vauban Fortresses in France (an example would be the Besancon Fortress in France, visited by some of the interviewed persons).

Suggested projects:

- Founding local tourism information points

- Setting up a promenade route that will include the Fortress Bulwarks, but also the Tower of the Orthodox Cathedral and of other tall buildings in the area

- Building/restoring a summer theatre in the Fortress's Bulwarks

- Setting up an amphitheatre within the interior bulwarks

- Setting up an open air museum

- Building a botanical garden, like the one in Cluj Napoca

- The electronic map of the town and of the touristic sites

3. The problem: the absence of a unitary brand that will allow the promotion, development and capitalizing of the touristic and entertainment opportunities of the Fortress.

Suggested projects:

- Elaborating a tourism strategy for Alba Iulia on medium and long term

- Elaborating a schedule of touristic events and organizing a major festival each month (the National Unity Days, the Medieval Theatre Days, the Local Traditions Days, the Religious Books Days, the Orthodoxy Days, the Catholicism Days, the Jewish Tradition Days, the Hungarian Days, the Italian Days, the Austrian Days, etc.)

- Conceiving, multilingual editing, multiplying and constantly disseminating tourism information and promotion products

- Promoting the objectives of the Fortress at the level of major national and foreign touroperators

- Participating at internal and external tourism fairs. 
4. The problem: the difficulty of the Fortress's territorial managing in the absence of a sole administration, either as a citizens or as a private association

Suggested projects:

- During the interviews we tested to idea of founding a GOVERNESS of the Fortress. The ideas exposed in the box below were accepted as a starting point for building a sole form of administration. The project draft of the Fortress's Governess is shown below:

$A$. The governess will be a private public partnership and the integrant factor could be the local public administration alongside which will participate the organizations involved in managing the cultural-historic patrimony of the Fortress (the "1 Decembrie 1918" University of Alba Iulia, the Orthodox Archiepiscopacy, the Roman-Catholic Archiepiscopacy, the Unification Museum, the Batthyaneum Library and other public or private organizations with major inventories within the patrimony), as well as public institutions or private organizations with major interests in the area of the Fortress (the County Council, the Prefecture, investors, NGOs, etc.).

$B$. The governess will be provided with partners who have spaces, a management, technical and financial apparatus, having the organizational capacity to collect and manage funds from the autonomous management of the well-defined territorial space of the historic Fortress.

C. In order to delimit the territory of the Governess, the local administration, as founder, and its partners will engage the adequate actions.

D. Three offices of tourism orientation can be set up. The offices will have access, orientation and informatics monitoring support (unique cards for entering all the objectives in the Fortress, which give the opportunity to access all the info-kiosks), as well as means for classic access, orientation and promotion (classic tickets, audio-video materials and in writing). Through the initial project integrated spatially, historically, etc., and beside the orientation function, the offices can be endowed with expositional or cultural-historic commercial spaces, without suffocating the orientation function.

E. In the space of the Governess it could have the capacity to collect funds from the tourism orientation offices, but also from other sources, such as: leasing spaces for setting up tourist attractions in accordance with the promotion and development Strategy for the Fortress, renting spaces given by the partners, other forms established through the founding statute.

\section{References:}

1. Datculescu, P., 2006. Marketing Research. How to get inside the consumer's mind, how to measure and analyse the information, Branbuilders Grup, Bucharest.

2. Muntean, A., Marina, L., 2008. Promotional strategy of Alba Iulia Fortress, in Annales Universitatis Apulensis Series Oeconomica, vol. 2, issue 10.

3. Krueger, R. A.; Casey, M.A., 2005. The Focus Groups: A Practical Guide for Applied Research Polirom, Iaşi. 